\title{
Phenotypic and environmental correlates of tooth eruption in red deer (Cervus elaphus)
}

\author{
Leif Egil Loe ${ }^{1,2}$, Erling L. Meisingset ${ }^{3}$, Atle Mysterud ${ }^{2 *}$, Rolf Langvatn ${ }^{1,4}$ and Nils C. Stenseth ${ }^{2}$ \\ ${ }^{1}$ University Center on Svalbard (UNIS), N-9170 Longyearbyen, Spitsbergen, Norway \\ 2 Department of Biology, Division of Zoology, University of Oslo, P.O. Box 1050 Blindern, N-0316 Oslo, Norway \\ ${ }^{3}$ Norwegian Center for Ecological Agriculture, N-6630 Tingvoll, Norway \\ ${ }^{4}$ Norwegian Institute for Nature Research, Tungasletta 2, N-7485 Trondheim, Norway \\ (Accepted 24 June 2003)
}

\begin{abstract}
In ungulates, a set of deciduous teeth is replaced by a set of permanent teeth during their first 2 years of life. Little is known about factors causing variation in timing of tooth eruption, but overall size, condition or mineral deficiencies may play a role. The pattern of incisor (I) and canine (C) eruption was investigated in 2241 yearlings from five populations of red deer Cervus elaphus in Norway during 1964-2001. Before the sampling period (10 September-15 November), $I_{1}$ had erupted in most yearlings (97\%), while eruption of $I_{3}$ and $C$ had barely started (erupted in $7 \%$ and $5 \%$ of individuals, respectively). Exactly $50 \%$ of the yearlings had erupted $\mathrm{I}_{2}$. Jawbone length was shown to be a main determining factor for eruption of $\mathrm{I}_{2}$. However, for a given jawbone length, there was large variation among populations in the proportion of yearlings with erupted $\mathrm{I}_{2}$ (from $<20 \%$ to $>75 \%$ ). Females got their permanent $I_{2}$ earlier than males. Tooth eruption was found to be later with increasing local deer density, even after correcting for body weight. There was a residual effect of body weight (a measure of condition) after body size (measured as jawbone length) was controlled for in one of five populations, indicating that overall condition may influence timing of tooth eruption in this area. There was no evidence that calcium was limiting for eruption, as no correlation was found between timing of eruption and limestone in bedrock. Since there is large variation in timing of tooth eruption among red deer populations even after controlling for differences in phenotype and environmental factors, genotypic variation may also play an important role for tooth eruption patterns.
\end{abstract}

Key words: dentition, morphology, phenotypic quality, limestone, population effect, Cervus elaphus

\section{INTRODUCTION}

Mammals use their teeth to acquire and chew food as a preparation for digestion. Hence, teeth are important for life-long performance (Hickman, Roberts \& Larson, 1997). Most mammals have evolved a system where a set of deciduous teeth is replaced by a set of permanent teeth that last the rest of the lifespan. Permanent teeth are larger than deciduous teeth, and eruption of permanent teeth cannot occur until the jawbone has reached a minimum size (McCance \& Brown, 1961; Smith, 1989). Across species, early tooth change is related to rapid body growth (Smith, 2000). Within a species, however, the sequence of tooth eruption is fixed and has for a long time been used in the age determination of young age classes (e.g. Severinghaus, 1949). Nevertheless, the

*All correspondence to: Atle Mysterud, Department of Biology, Division of Zoology, University of Oslo, P.O. Box 1050 Blindern, N-0316 Oslo, Norway. E-mail: atle.mysterud@bio.uio.no timing and duration of eruption do vary among individuals of similar age (Robinette et al., 1957; Tisdall, Wilson \& Kirk, 1985). The biochemical processes involved in the control of tooth eruption are well known. During eruption, cells, proteins and enzymes change in the dental follicle and several growth factors and proteins accelerate or retard eruption rate (for a review see Marks, Gorski \& Wise, 1995). However, the relationship between rate of tooth eruption and variation in life-history traits and environmental factors in mammals is not well understood. In addition to size, it is expected that eruption is delayed: (1) by generally low body condition, or (2) in areas with mineral deficiencies.

(1) Low body condition (i.e. a residual effect of weight after controlling for height; Green, 2001) delayed eruption of permanent teeth in humans (Kaur \& Singh, 1992). However, the effect of body condition was not large and it is assumed that most of the variation in human dentition is explained by genetic variance among populations (Garn \& Rohmann, 1962; Garn, Lewis \& Kerewski, 
1965; Friedlander \& Bailit, 1969; Kaur \& Singh, 1992). In ungulates, only two studies have investigated the relationship between tooth development and somatic growth, but neither of them have separated the effects of body size and body weight. Robinette et al. (1957) found that the number of erupted incisors increased with body weight in mule deer Odocoileus hemionus, and Lutz (1993) provide graphical evidence that individual fallow deer Dama dama with short mandible and low body weight erupt their first molar later than larger conspecifics. No studies of ungulates have investigated variation among different populations.

(2) Calcium, in addition to phosphorus, is a limiting element in the formation of bone (Bazely, 1989) and teeth (Fortelius, 1985). Calcium deficiency in forage was found to cause dental disease in pet rabbits Oryctolagus cuniculus (Harcourt Brown, 1996). Tooth eruption was delayed in six weaning sheep Ovis aries fed on cereal roughages poor in calcium, compared to five sheep where ground limestone was added to the diet (Franklin, 1950). No study has explored whether calcium is limiting for tooth development in natural populations of mammals.

This paper gives a report on how variation in the tooth eruption of 2241 yearling red deer Cervus elaphus was related to phenotypic (jawbone size, body weight and body condition) and environmental variables (bedrock calcium, local density and distance from the coast). Our study is based on data from five different populations along the west coast of Norway, sampled between 10 September and 15 November 1964-2001. The prediction that eruption is earlier in larger and fatter deer was tested. The density of local deer and their distance from the coast are known to correlate, respectively, negatively and positively with red deer body weight (Mysterud, Langvatn et al., 2001; Mysterud, Yoccoz et al., 2001). Later eruption of permanent teeth with increasing deer density, and earlier eruption with increasing distance from the coast was therefore expected, but no residual effect after body weight was also entered in the model if the effect of density and distance from the coast operated only through body weight. Lastly, earlier eruption in areas with calcium rich bedrock was predicted.

\section{MATERIAL AND METHODS}

\section{Study area}

The study area (covering 65 municipalities) encompasses large parts of the Norwegian south-west coast (Fig. 1), which is the main area for red deer in Norway (Langvatn et al., 1996; Mysterud, Yoccoz et al., 2001). In earlier studies (e.g. Mysterud, Langvatn et al., 2002), red deer from this area were divided into 5 populations: Rogaland and Hordaland, population P1; Sogn og Fjordane, population P2; Møre og Romsdal and Sør-Trøndelag, population P3; Nord-Trøndelag, population P4; Hitra island, population P5 (Fig. 1). There has been a large

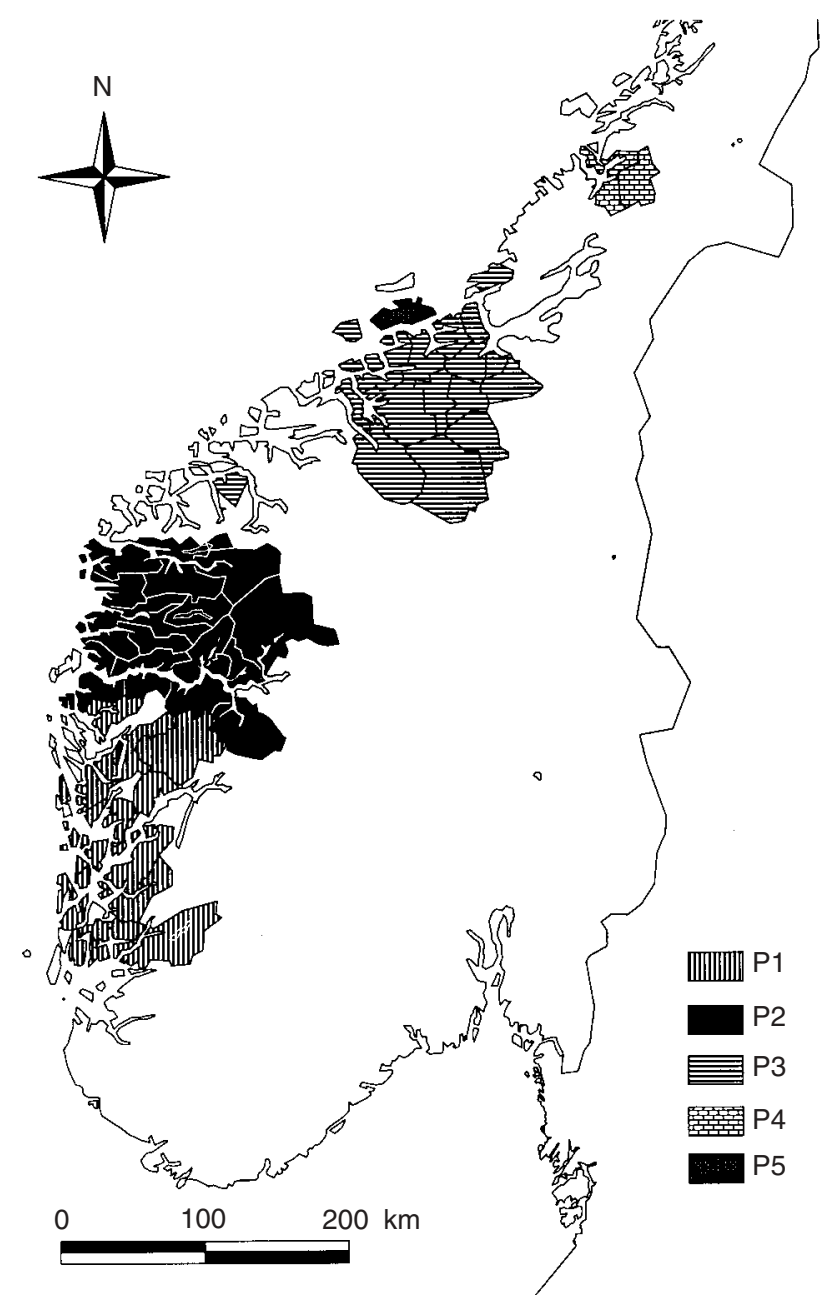

Fig. 1. Map showing the study area covering 65 municipalities on the west coast of Norway, where white lines show municipality borders. Red deer Cervus elaphus are divided into five different populations (P1-P5) based on earlier studies on population dynamics of Norwegian red deer.

increase in the population density of red deer during the study period, and density-dependent effects on body weight have been reported (e.g. Mysterud, Yoccoz et al., 2001). In general, temperature and precipitation decline from south to north and from coast to inland, while snow depth increases (Langvatn et al., 1996; Mysterud, Yoccoz et al., 2000). In summer, both the length of the growing season and total degree days decline from south-west to north-east (Langvatn \& Albon, 1986).

\section{Red deer data}

A total of 2241 mandibles from yearling red deer was sampled during the annual autumn harvest 1964-2001 (between 10 September and 15 November), together with data on body weights and records of date of culling and locality (municipality; Langvatn et al., 1996; Mysterud, Langvatn et al., 2002). Mandibles of yearlings can easily be separated from older animals owing to distinct 
tooth eruption patterns and mandible length (Mitchell \& Youngson, 1969). Body weight is dressed weight (i.e. live weight minus head, skin, viscera, bleedable blood and metapodials, $c$. 58\% of live weight; Langvatn, 1977). Jaw length was measured according to Langvatn (1977).

The incisor teeth and canines $\left(\mathrm{I}_{1}-\mathrm{C}\right)$ were considered, because development of these teeth show a large variation within our sampling period. September and October represents the time of the largest individual variation in the eruption status of permanent incisors in mule deer (Robinette et al., 1957). For each tooth, the score 1 was assigned if the permanent tooth was visible above either of the mandible halves, and score 0 was assigned if permanent tooth was not visible or if the jaw still had deciduous teeth.

\section{Geological data}

Data on bedrock geology were obtained from the Geological Survey of Norway (NGU; the vector map used can be found on www.ngu.no). The proportion of each bedrock type for each municipality was calculated by using overlay analyses in ArcView GIS version 3.2 (Environmental Systems Research Institute Inc., CA, U.S.A.). Bedrock types were grouped into 3 groups according to calcium level (high, low, and unknown) and their proportion summarized. Mineral solubility (i.e. the amount of free calcium available) is more important than the absolute amount of $\mathrm{CaO}$ in each bedrock type. Bedrock types in the 'high calcium' group are highly soluble and consisted of up to $56 \% \mathrm{CaO}$, while bedrock types in the 'low calcium' group consist of up to $20 \% \mathrm{CaO}$ and are less soluble (Ø. Nordgulen, pers. comm.; Taylor \& McLennan, 1985). In no municipality was the proportion of bedrock with unknown calcium content higher than 0.02 . The proportion of 'high calcium' bedrock in each municipality (a number ranging from 0 to 0.92 ) was used as the predictor in our analysis.

\section{Statistical analyses}

Generalized linear models (GLM; see Venables \& Ripley, 1999) were used with a binomial response (i.e. logistic regression) in the analyses of the timing of tooth eruption. Weight and jawbone length were ln-transformed to stabilize the variance. Other covariates included were date of culling, calcium level in bedrock (see above), an index for local population density (Mysterud, Yoccoz et al., 2001), and distance from the coast, which is known to be a main determinant of body weight and ovulation rates (Langvatn \& Albon, 1986; Langvatn et al., 1996; Mysterud, Langvatn et al., 2001). Condition was assessed as the residual of body weight after body size (jawbone length) was entered in the model (Green, 2001). The effect of interactions of 2 continuous variables was analysed by using the product of the 2 standardized variables as a separate term (Portier et al., 1998). AIC was used when performing model selection (Burnham \& Anderson, 1998). As we were testing specific hypotheses, a model with main (predicted) effects was run first. Then AIC was used to evaluate whether more complicated models (i.e. by adding interactions) improved the fit or not, since there were no a priori biological predictions for interactions. We ran the basic model both with and without including body weight, as the effect of body weight may affect estimates of other factors (such as density). Goodness-of-fit (GOF) of the logistic regression models could not be properly assessed on the basis of the residual deviance or Pearson residuals because observations were unique (i.e. 0/1) (see e.g. McCullagh \& Nelder, 1989). Residual deviances were, however, less than their associated number of degrees of freedom (residual deviance $=2098.219$, d.f. $=2226$ and residual deviance $=2079.628$, d.f. $=2221$, respectively, for models without and with body weight included), so we had no indication of overdispersion. All statistical analyses were performed in the statistical package S-Plus (Insightful, Seattle, WA, U.S.A.).

\section{RESULTS}

In our material, the permanent first incisor had erupted in most yearling red deer $(96.9 \%$ for all populations combined), while the third incisor and canines had rarely erupted $(6.6 \%$ and $5.0 \%$, respectively; Table 1$)$. Eruption of the second incisor $\left(\mathrm{I}_{2}\right)$ was the most variable, being erupted in $49.8 \%$ of the yearlings (Table 1 ). We therefore used $I_{2}$ in subsequent analysis of factors affecting tooth eruption, as logistic regression analyses performs best when failure and success rates are approximately even (Hosmer \& Lemeshow, 1989).

The second incisor $\left(\mathrm{I}_{2}\right)$ was erupted more often in yearlings with a long jawbone (Fig. 2; Table 2). For a given jawbone length, however, the likelihood that $\mathrm{I}_{2}$ had erupted showed a wide variation among the five red deer populations (Table 2; Fig. 2). The population effect did not correspond to the variation in latitude; timing of eruption in P1 (the southernmost population) is later than in P2, while individuals in P4, P3 and P5 had a similar eruption pattern although variation in latitude is large (Figs 1 \& 2). Incisor eruption occurred earlier in females than in males (females: $52.5 \%$; males: $49.0 \%$; standardized for mean date). After accounting for size differences, the effect of sex was even stronger; $63.2 \%$ of females and $46.8 \%$ of males had erupted second incisors (for the mean date and mean jaw length). Adding interactions between 'population and sex' $(\mathrm{AIC}=2129,2)$, 'population and jawbone length' $(\mathrm{AIC}=2127,2)$ or 'population and density' (AIC $=2125,4)$ resulted in significantly less parsimonious models as compared to the model including only the main effects $(\mathrm{AIC}=2121,8)$.

The amount of calcium in the bedrock or distance from the coast did not affect timing of incisor eruption (Table 2). Local (municipal) deer density delayed eruption of $\mathrm{I}_{2}$ (Table 2a). The effect of density decreased, but 
Table 1. Eruption status of permanent front teeth in yearlings ( $n=2241$ individuals) in five populations of Norwegian red deer Cervus elaphus (P1-P5). Individuals were sampled between 10 September and 15 November. Tooth types were considered to be erupted if visible above the jawbone on at least one of the mandible halves

\begin{tabular}{|c|c|c|c|c|c|c|c|}
\hline & & $\mathrm{P} 1$ & $\mathrm{P} 2$ & $\mathrm{P} 3$ & $\mathrm{P} 4$ & P5 & All populations \\
\hline 1. Incisor & $\begin{array}{l}\text { Erupted } \\
\text { Not erupted } \\
\% \text { erupted }\end{array}$ & $\begin{array}{c}673 \\
8 \\
98.8\end{array}$ & $\begin{array}{l}718 \\
11 \\
98.5\end{array}$ & $\begin{array}{l}558 \\
35 \\
94.1\end{array}$ & $\begin{array}{c}64 \\
0 \\
100.0\end{array}$ & $\begin{array}{l}159 \\
15 \\
91.4\end{array}$ & $\begin{array}{c}2172 \\
69 \\
96.9\end{array}$ \\
\hline 2. Incisor & $\begin{array}{l}\text { Erupted } \\
\text { Not erupted } \\
\% \text { erupted }\end{array}$ & $\begin{array}{c}406 \\
275 \\
59.6\end{array}$ & $\begin{array}{c}548 \\
181 \\
75.2\end{array}$ & $\begin{array}{c}104 \\
489 \\
17.5\end{array}$ & $\begin{array}{l}26 \\
38 \\
40.6\end{array}$ & $\begin{array}{c}31 \\
143 \\
17.8\end{array}$ & $\begin{array}{c}1115 \\
1126 \\
49.8\end{array}$ \\
\hline 3. Incisor & $\begin{array}{l}\text { Erupted } \\
\text { Not erupted } \\
\% \text { erupted }\end{array}$ & $\begin{array}{r}48 \\
633 \\
7.0\end{array}$ & $\begin{array}{c}83 \\
646 \\
11.4\end{array}$ & $\begin{array}{r}5 \\
588 \\
0.8\end{array}$ & $\begin{array}{c}2 \\
62 \\
3.1\end{array}$ & $\begin{array}{r}10 \\
164 \\
5.7\end{array}$ & $\begin{array}{r}148 \\
2093 \\
6.6\end{array}$ \\
\hline Canine & $\begin{array}{l}\text { Erupted } \\
\text { Not erupted } \\
\% \text { erupted }\end{array}$ & $\begin{array}{c}39 \\
642 \\
5.7\end{array}$ & $\begin{array}{c}59 \\
670 \\
8.1\end{array}$ & $\begin{array}{c}4 \\
589 \\
0.7\end{array}$ & $\begin{array}{c}0 \\
64 \\
0.0\end{array}$ & $\begin{array}{c}10 \\
164 \\
5.7\end{array}$ & $\begin{array}{r}112 \\
2129 \\
5.0\end{array}$ \\
\hline
\end{tabular}

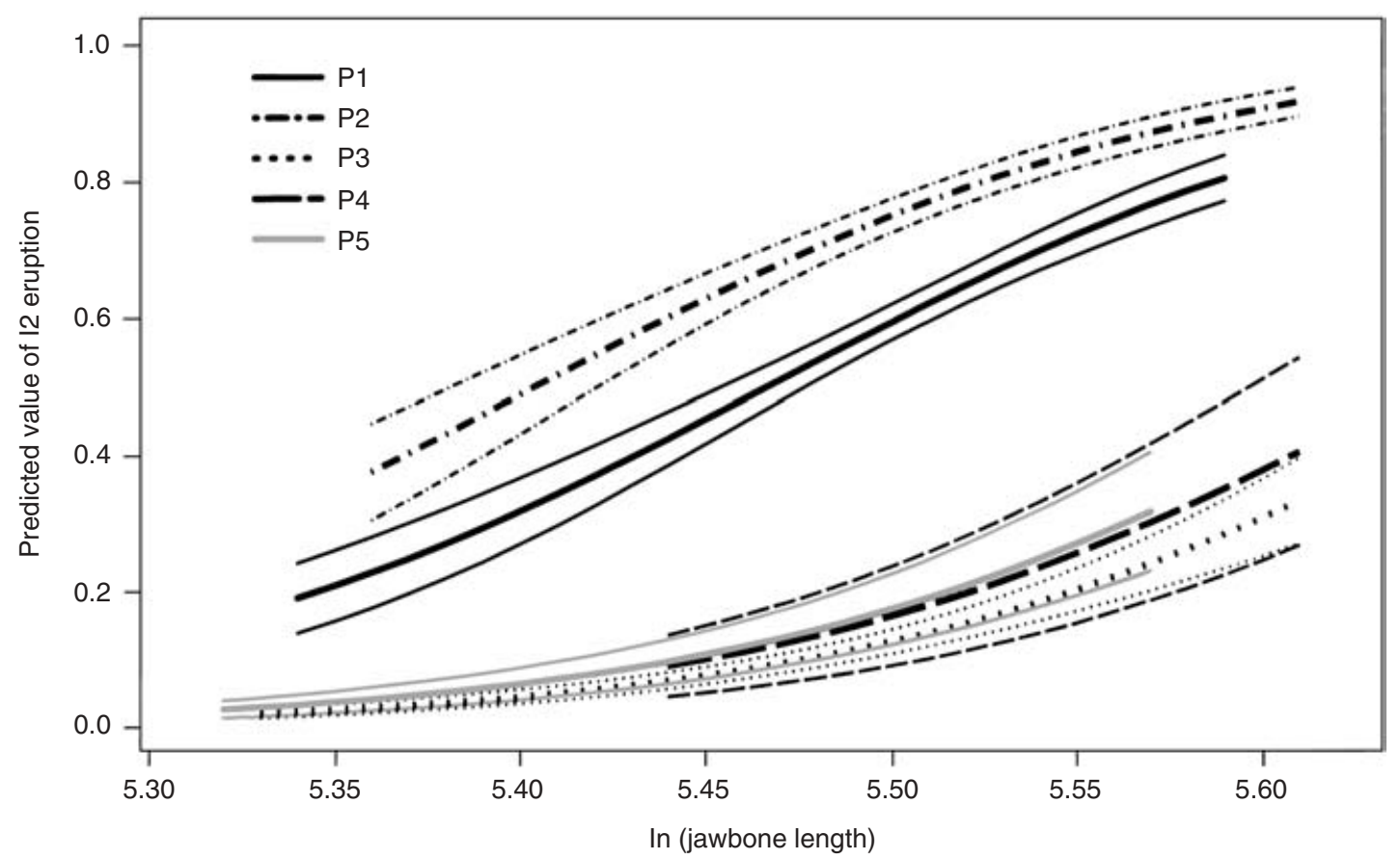

Fig. 2. Probability (with $95 \% \mathrm{CI}$ ) of tooth eruption $\left(\mathrm{I}_{2}\right)$ as a function of jawbone length (ln-transformed) and population (P1-P5) in male red deer Cervus elaphus yearlings. All other factors (listed in Table 2) are controlled for by including average values. Predicted values are plotted only for intervals where real jawbone length data are present (explaining the small interval variations on the $\mathrm{x}$-axis among populations).

remained significant after body weight was added to the model (Table 2b). There was also a residual effect of body weight after jawbone length was controlled for (Table $2 b$ ), suggesting that individuals in good condition develop permanent teeth earlier than individuals in poor condition. Adding the interaction between 'population and body weight' $(\mathrm{AIC}=2111,6)$ resulted in a better model than the one including only main effects $(\mathrm{AIC}=2118,7)$. The condition effect was significant only in population $\mathrm{P} 1$, and not in the remaining populations (P2, P3, P4 and P5) when running separate models.

\section{DISCUSSION}

Ungulates sequentially replace a set of deciduous front teeth with a set of permanent front teeth during their first 2 years; starting with the first incisors $\left(\mathrm{I}_{1}\right)$ and ending with the canines (C) (Robinette et al., 1957). A large variation was found in the eruption status for all types of front teeth. Some yearlings had completed eruption of their permanent front teeth by 10 September, while others had not initiated eruption of any front teeth by 15 November. The most variable eruption was found for 
Table 2. Two models showing the relationship between eruption of $I_{2}$ and various predictor variables; the first model (a) excluding body weight and the second (b) including body weight. Parameter estimates are obtained from the GLM, i.e., least squares estimates and associated standard errors (SE) and $95 \%$ confidence intervals. The reference level for the factor sex is 'female' and for the factor 'population' is $\mathrm{P} 1$. Other parameters are given as the difference between levels

\begin{tabular}{|c|c|c|c|c|}
\hline \multirow[b]{2}{*}{ (a) Model excluding body weight } & \multirow[t]{2}{*}{ Parameter estimate } & \multirow[t]{2}{*}{ SE } & \multicolumn{2}{|c|}{$95 \% \mathrm{CI}$} \\
\hline & & & & \\
\hline Intercept & -76.7 & 8.41 & -93.5, & -59.9 \\
\hline Current density & -0.516 & 0.130 & -0.776 & -0.257 \\
\hline Jawbone length & 13.9 & 1.54 & 10.8 & 17.0 \\
\hline Distance to coast & 0.173 & 0.142 & -0.110 & 0.457 \\
\hline Date of culling & 0.0448 & 0.00289 & 0.0390 & 0.0505 \\
\hline Population (P2-P1) & 0.760 & 0.171 & 0.419 & 1.10 \\
\hline Population (P3-P1) & -2.39 & 0.165 & -2.72 & -2.06 \\
\hline Population (P4-P1) & -1.11 & 0.303 & -1.72 & -0.509 \\
\hline Population (P5-P1) & -1.48 & 0.308 & -2.09 & -0.861 \\
\hline $\operatorname{Sex}(M-F)$ & -0.637 & 0.132 & -0.901 & -0.374 \\
\hline Calcium in bedrock & -0.674 & 0.360 & -1.39 & 0.0467 \\
\hline \multicolumn{5}{|l|}{ (b) Model including body weight } \\
\hline Intercept & -70.7 & 9.89 & -90.5 & -50.9 \\
\hline Current density & -0.394 & 0.138 & -0.669 & -0.119 \\
\hline Jawbone length & 11.4 & 2.00 & 7.36 & 15.4 \\
\hline Body weight & 2.03 & 0.678 & 0.675 & 3.39 \\
\hline Distance to coast & 0.174 & 0.144 & -0.115 & 0.462 \\
\hline Date of culling & 0.0455 & 0.00293 & 0.0397 & $\quad 0.0514$ \\
\hline Population (P2-P1) & 6.17 & 3.09 & -0.0106 & 12.3 \\
\hline Population (P3-P1) & 6.86 & 4.16 & -1.47 & 15.2 \\
\hline Population (P4-P1) & -23.0 & 12.9 & -48.7 & 2.71 \\
\hline Population (P5-P1) & 13.0 & 5.57 & 1.82 & 24.1 \\
\hline $\operatorname{Sex}(M-F)$ & -0.698 & 0.135 & -0.969 & -0.428 \\
\hline Calcium in bedrock & -0.620 & 0.364 & -1.35 & 0.108 \\
\hline Body weight $\times$ population $(\mathrm{P} 2-\mathrm{P} 1)$ & -1.40 & 0.795 & -2.99 & 0.191 \\
\hline Body weight $\times$ population $(\mathrm{P} 3-\mathrm{P} 1)$ & -2.36 & 1.05 & -4.45 & -0.260 \\
\hline Body weight $\times$ population $(\mathrm{P} 4-\mathrm{P} 1)$ & 5.38 & 3.18 & -0.983 & 11.7 \\
\hline Body weight $\times$ population (P5-P1) & -3.82 & 1.48 & -6.79 & -0.854 \\
\hline
\end{tabular}

$\mathrm{I}_{2}$ with $50 \%$ erupted, and variation in eruption of $\mathrm{I}_{2}$ was our target for analysis.

\section{Size effects}

Jawbone length correlated well with the timing of incisor eruption within all five populations of red deer. This pattern was expected because tooth development must be timed to growth of the skull, maturation of muscles of mastication, and somatic growth in general (Smith, 1989). It is essential for the jaw to be the right size before teeth erupt in order to form an exact fit between the occlusal surfaces (Pond, 1977). Overcrowding and torsion of permanent incisors was reported in undernourished sheep with small mandibles (Franklin, 1950). Age may be an additional factor affecting body size or timing of tooth eruption directly, and that can possibly affect the pattern of tooth eruption. The observed variation in timing of front teeth eruption between populations, however, seems too large to be explained solely by different calving dates, as births are fairly synchronous in red deer (e.g. Guinness, Gibson \& Clutton-Brock, 1978). In a captive population in Norway, $80 \%$ of calves were born between 31 May and 23 June ( 23 days; $n=56$ ). Further, a latitudinal gradient would have been expected if calving dates were a confounding factor leading to the observed variation in tooth eruption between populations, but such a pattern was not evident. For example, population P2 erupted before $\mathrm{P} 1$ and $\mathrm{P} 3$ which are respectively south and north of $\mathrm{P} 2$.

\section{Density dependence and body condition}

Eruption of $I_{2}$ in yearlings was delayed at high population density. This was expected, since increasing population density adversely affects early growth and body weight in ungulates (review in Lindström, 1999; Gaillard et al., 2000), and which is also true for red deer on the west coast of Norway (Mysterud, Yoccoz et al., 2001). Indeed, the density-dependent delay of eruption decreased in strength when body weight was added to the model, but a residual density effect suggests that factors other than weight also affect this relationship. A positive effect of body condition (residual of weight after body size is controlled for) indicates that the process of eruption of permanent teeth contains an element of resource investment, which was observed in humans (Kaur \& Singh, 1992). A positive relationship between body weight 
and early eruption of permanent teeth was observed in both mule deer (Robinette et al., 1957) and fallow deer (Lutz, 1993), but they did not control for body size. For yearling red deer, body condition was found to affect eruption in only one of the five populations; hence no consistent link between body condition and eruption was found.

\section{Earlier tooth eruption in females than males}

Females were found to erupt their second incisors earlier than males. The sexual variation in eruption persisted and increased when controlling for differences in jaw length. Red deer are sexually dimorphic even as yearlings (Clutton-Brock, Guinness \& Albon, 1982). Permanent teeth scales to body size, and female teeth are smaller than male teeth (Loe et al., 2003). Teeth therefore seem to be able to erupt in a smaller jaw in females without resulting in malocclusion and torsion. Earlier studies on the timing of molar eruption in mule deer found no effect of sex (Robinette et al., 1957; Rees, Kainer \& Davis, 1966). In humans, however, females erupt permanent teeth earlier than males (Friedlaender \& Bailit, 1969), which is consistent with our results for red deer.

\section{Calcium and tooth eruption}

The deposition of salts in the early-forming teeth is affected considerably by various factors of metabolism (Guyton \& Hall, 2000). Calcium is a key element in the formation of hydroxyapatite, which is the major material of tooth enamel and dentin (Guyton \& Hall, 2000). Calcium deficiency tended to cause delay in tooth eruption in an experimental study of sheep in Australia ( $n=11$; Franklin, 1950). Therefore a delayed eruption was expected in municipalities with a low content of calcium in bedrock, but we failed to find evidence for this. Calcium content therefore seems not to be limiting for tooth formation in our study area. Plant material may have the same mineral content even when mineral content in the soil is variable (Hrdlicka \& Kula, 1998). Forage selection may also differ in calcium rich and calcium deficient areas so that any difference in mineral content is compensated for (McNaughton, 1988; McNaughton, 1990). In herbivores this may even take the extreme form of carnivory (Furness, 1988; Bazely, 1989; Pietz \& Granfors, 2000) or geophagy (Klaus \& Schmid, 1998). The possibility that elements other than calcium may also play a role cannot be excluded. The level of phosphorus or the ratio of calcium/phosphorus may also be important for development of bone structure in mammalian herbivores (e.g. Ohlson \& Staaland, 2001), and there is evidence suggesting that geophagia, osteophagia and other forms of pica behaviour in ungulates also occur as a consequence of phosphorus deficiency in the diet (Blair-West et al., 1992; WallisDeVries, 1996).

\section{Phenotype vs. genotype}

For the same jaw length, the probability of incisors erupting varied from $<20 \%$ to $75 \%$ among populations (Fig. 2). Emergence times of permanent teeth have also been reported to differ among human populations (e.g. Friedlaender \& Bailit, 1969) and many studies of human tooth eruption have concluded that genotypic variation is the main determinant in tooth emergence (Garn \& Rohmann, 1962; Friedlander \& Bailit, 1969; Kaur \& Singh, 1992). As there is large variation in the timing of tooth eruption among red deer populations even after controlling for differences in phenotype and environmental factors, genotype may also play an important role for tooth eruption in red deer.

\section{Acknowledgements}

We thank Nigel G. Yoccoz for statistical advice, and Vebjørn Veiberg for valuable help during laboratory work. Øystein Nordgulen (Geological Survey of Norway) and Klaus Høiland provided valuable help for defining calcium content in bedrock types. We gratefully acknowledge the financial support given by the Research Council of Norway (NFR) to LEL and AM.

\section{REFERENCES}

Bazely, D. R. (1989). Carnivorous herbivores: mineral nutrition and the balanced diet. Trends Ecol. Evol. 4: 155-156.

Blair-West, J. R., Denton, D. A., McKinley, M. J., Radden, B. G., Ramshaw, E. H. \& Wark, J. D. (1992). Behavioral and tissue responses to severe phosphorus depletion in cattle. Am. J. Physiol. 263: R656-R663.

Burnham, K. P. \& Anderson, D. R. (1998). Model selection and inference: a practical information-theoretic approach. New York: Springer.

Clutton-Brock, T. H., Guinness, F. E. \& Albon, S. D. (1982). Red deer. Behaviour and ecology of two sexes. Edinburgh: Edinburgh University Press.

Fortelius, M. (1985). Ungulate cheek teeth: developmental, functional, and evolutionary interrelations. Acta Zool. Fenn. 180: $1-76$.

Franklin, M. C. (1950). The influence of diet in dental development of sheep. Commonw. Sci. Indus. Res. Org. Bull. No. 252: 1-34.

Friedlaender, J. S. \& Bailit, H. L. (1969). Eruption times of the deciduous and permanent teeth of natives on Bouganville island, territory of New Guinea: a study of racial variation. Hum. Biol. 41: $51-65$.

Furness, R. W. (1988). Predation on ground-nesting seabirds by island populations of red deer Cervus elaphus and sheep Ovis. J. Zool. (Lond.) 216: 565-573.

Gaillard, J.-M., Festa-Bianchet, M., Yoccoz, N. G., Loison, A. \& Toïgo, C. (2000). Temporal variation in fitness components and population dynamics of large herbivores. Annu. Rev. Ecol. Syst. 31: $367-393$.

Garn, S. M., Lewis, A. B. \& Kerewski, R. S. (1965). Genetic, nutritional and maturational correlates of dental development. J. Dent. Res. 44: 228-242.

Garn, S. M. \& Rohmann, C. G. (1962). X-Linked inheritance of developmental timings in man. Nature (Lond.) 196: 695696. 
Green, A. J. (2001). Mass/length residuals: measures of body condition or generators of spurious results? Ecology 82: 14731483.

Guinness, F. E., Gibson, R. M. \& Clutton-Brock, T. H. (1978). Calving times of red deer (Cervus elaphus) on Rhum. J. Zool. (Lond.) 185: 105-114.

Guyton, A. C. \& Hall, J. E. (2000). Textbook of the medical physiology. 10th edn. Philadelphia: W. B. Sauders.

Harcourt Brown, F. M. (1996). Calcium deficiency, diet and dental disease in pet rabbits. Vet. Rec. 139: 567-571.

Hickman, C. P., Roberts, L. S. \& Larson, A. (1997). Integrated principles of zoology. 10th edn. Boston: WCB/McGraw-Hill.

Hosmer, D. W. \& Lemeshow, S. (1989). Applied logistic regression. New York: Wiley.

Hrdlicka, P. \& Kula, E. (1998). Element content in leaves of birch (Betula verrucosa Ehrh.) in an air polluted area. Trees Struct. Funct. 13: 68-73.

Kaur, B. \& Singh, R. (1992). Physical growth and age at eruption of deciduous and permanent teeth in well-nourished Indian girls from birth to 20 years. Am. J. Hum. Biol. 4: 757-766.

Klaus, G. \& Schmid, B. (1998). Geophagy at natural licks and mammal ecology: a review. Mammalia 62: 481-497.

Langvatn, R. (1977). Criteria of physical condition, growth and development in Cervidae - suitable for routine studies. Stockholm: Nordic Council for Wildlife Research.

Langvatn, R. \& Albon, S. D. (1986). Geographic clines in body weight of Norwegian red deer: a novel explanation of Bergmann's rule? Holarct. Ecol. 9: 285-293.

Langvatn, R., Albon, S. D., Burkey, T. \& Clutton-Brock, T. H. (1996). Climate, plant phenology and variation in age at first reproduction in a temperate herbivore. J. Anim. Ecol. 65: 653670.

Lindström, J. (1999). Early development and fitness in birds and mammals. Trends Ecol. Evol. 14: 343-348.

Loe, L. E., Mysterud, A., Langvatn, R. \& Stenseth, N. C. (2003). Decelerating and sex-dependent tooth wear in Norwegian red deer. Oecologia (Berl.) 135: 346-353.

Lutz, W. (1993). Beitrag zur Zahn- und Unterkieferentwicklung bei Damwildkälbern aus einem grosstädtischen Ballungsraum. Z. Jagdwiss. 39: 73-86.

Marks, S. C., Gorski, J. P. \& Wise, G. E. (1995). The mechanisms and mediators of tooth eruption - models for developmental biologists. Int. J. Dev. Biol. 39: 223-230.

McCance, R. A. \& Brown, W. A. B. (1961). Severe undernutrition in growing of adult animals. 7. Development of the skull, jaws and teeth in pigs. Br. J. Nutr. 15: 213-224.

McCullagh, P. \& Nelder, J. A. (1989). Generalized linear models. London: Chapman and Hall.

McNaughton, S. J. (1988). Mineral nutrition and spatial concentrations of African ungulates. Nature (Lond.) 334: 343-345.

McNaughton, S. J. (1990). Mineral nutrition and seasonal movements of African migratory ungulates. Nature (Lond.) 345: 613615.

Mitchell, B. \& Youngson, R. W. (1969). Teeth and age in Scottish red deer-a practical guide to the determination of age. The Red deer Commision Annual Report for 1968: appendix. London: The Red Deer Commission, H.M.S.O.

Mysterud, A., Langvatn, R., Yoccoz, N. G. \& Stenseth, N. C. (2001). Plant phenology, migration and geographic variation in body weight of a large herbivore: the effect of a variable topography. J. Anim. Ecol. 70: 915-923.

Mysterud, A., Langvatn, R., Yoccoz, N. G. \& Stenseth, N. C. (2002). Large-scale habitat variability, delayed density effects and red deer populations in Norway. J. Anim. Ecol. 71: 569-580.

Mysterud, A., Yoccoz, N. G., Stenseth, N. C. \& Langvatn, R. (2000). Relationships between sex ratio, climate and density in red deer: the importance of spatial scale. J. Anim. Ecol. 69: 959974.

Mysterud, A., Yoccoz, N. G., Stenseth, N. C. \& Langvatn, R. (2001). The effects of age, sex and density on body weight of Norwegian red deer: evidence of density-dependent senescence. Proc. $R$. Soc. Lond. B Biol. Sci. 268: 911-919.

Ohlson, M. \& Staaland, H. (2001). Mineral diversity in wild plants benefits and bane for moose. Oikos 94: 442-454.

Pietz, P. J. \& Granfors, D. A. (2000). White-tailed deer (Odocoileus virginianus) predation on grassland songbird nestlings. Am. Midl. Nat. 144: 419-422.

Pond, C. M. (1977). The significance of lactation in the evolution of mammals. Evolution 31: 177-199.

Portier, C., Festa-Bianchet, M., Gaillard, J.-M., Jorgenson, J. T. \& Yoccoz, N. G. (1998). Effects of density and weather on survival of bighorn sheep lambs (Ovis canadensis). J. Zool. (Lond.) 245: 271-278.

Rees, J. W., Kainer, R. A. \& Davis, R. W. (1966). Chronology of mineralization and eruption of mandibular teeth in mule deer. J. Wildl. Manage. 30: 629-631.

Robinette, W. L., Jones, D. A., Rogers, G. \& Gashwiler, J. S. (1957). Notes of tooth development and wear for Rocky Mountain mule deer. J. Wildl. Manage. 21: 134-153.

Severinghaus, C. N. (1949). Tooth development and wear as criteria of age in white-tailed deer. J. Wildl. Manage. 13: 195216.

Smith, B. H. (1989). Dental development as a measure of life history in primates. Evolution 43: 683-688.

Smith, B. H. (2000). 'Schultz's rule' and the evolution of tooth emergence and replacement patterns in primates and ungulates. In Development, function and evolution of teeth: 212-227. Teaford, M. F., Meredith Smith, M. \& Ferguson, M. W. J. (Eds). Cambridge: Cambridge University Press.

Taylor, S. R. \& McLennan, S. M. (1985). The continental crust: its composition and evolution. Oxford: Blackwell Scientific.

Tisdall, J. S., Wilson, P. R. \& Kirk, E. J. (1985). Eruption pattern of the permanent incisor teeth of farmed red deer. In Biology of deer production: 409-410. Fennessy, P. F. \& Drew, K. R. (Eds). Wellington: The Royal Society of New Zealand.

Venables, W. N. \& Ripley, B. D. (1999). Modern Applied Statistics with S-plus. 3rd edn. New York: Springer.

WallisDeVries, M. F. (1996). Nutritional limitations of free-ranging cattle: the importance of habitat quality. J. Appl. Ecol. 33: 688702 . 